\title{
FROM A VISITOR TO PARTICIPANT. STRATEGIES FOR PARTICIPATION IN MUSEUMS
}

\begin{abstract}
The aim of this article is to reflect on the new position of the audience in museums which has been evolving from a passive to a more active role. The context for this reflection is Nina Simon's concept of the participatory museum. I discuss the issue using the examples of four museums in Poland where the changing attitude towards the visitor is a part of the general transformation of museums after the political transition of 1989. Selected case studies are: the project "Anything Goes" (2016) realised by the National Museum in Warsaw, the "Selfservice Museum" (since 2012) realised by the Contemporary Museum Wrocław, the "ms3 Re:action" (2009) conducted by the Museum of Art in Łódź, and the "Free Museum in Wolnica Square. Kazimierz Collective" (since 2013) realised by the Ethnographic Museum in Kraków. My thesis is that although visitors are encouraged to engage and participate in museum programmes, they are involved or seemingly involved to a limited extent.
\end{abstract}

SŁOWA KLUCZE: muzeum partycypacyjne, uczestniczyć, angażować się, Nina Simon

KEY WORDS: participatory museum, participate, engage, Nina Simon

\section{Introduction}

The turn of the $21^{\text {st }}$ century marks the period of intensified changes in museums all over the world. The number of newly established museums is greater than ever, and also old museums expand their spaces and redevelop programme strategies. Education, audiences, participation and inclusion have become the keywords of the 'museum age' that started around 1980s. Although the development, protection and research of collections are still the core of interests of museums, visitors are gaining an equally key position. Dorota Folga-Januszewska concluded her recent book that - contrary to previous decades and centuries - contemporary museums are meant for individuals, not for groups or masses. She writes: 
The museology came full circle. After almost two thousand years of the history of museums as meeting places and spaces of intellectual inspiration, after two centuries of activities for "citizens," museums again look for individual visitors. ${ }^{1}$

Museums have to change to keep/gain/regain their topical place in societies. Graham Black argues that "If museums do not change to respond flexibly and rapidly to changing public demand, that public will go elsewhere." And he adds: "people today increasingly refuse to be passive recipients of whatever governments, companies or cultural institutions such as museums offer." ${ }^{3}$ Learning through engagement and through entertainment that requires involvement is the recipe (at least one of them) for successful contemporary museums. As Black puts it, museums should aim at

[...] engaging with users as active participants, contributors and collaborators on a learning journey together, rather than as passive recipients of museum wisdom; reaching out to build relationships and partner their communities; continuing to change and take on new meanings and roles as society continues to transform itself. ${ }^{4}$

Engaging audiences in museum programmes and involving them as co-creators has been a strategy eagerly employed in Western museums since at least 1990s, and in Poland since the coming of the new century, where it coincides with the museum building boom and 'educational turn.'

The offer of educational and public programmes in Polish museums, following the worldwide trend, has been expanding and diversifying to attract various audiences. Change postulated by Black is in Polish museological discourse identified with opening the museums up to participatory programmes and projects that - among other aims - serve to create inviting and engaging institutions that are meaningful and bring social change.

\section{Aim and structure of the article}

The aim of this article is to reflect on the new position of the audience in museums which has been evolving from a passive to more active role. The context for this reflection will be Nina Simon's ${ }^{5}$ concept of the participatory museum. I will discuss the issue using the example of museums in Poland where the changing attitude towards the visitor is a part of the general transformation of museums after the political transition of 1989. My hypothesis is that although visitors are encouraged to engage and participate in museum programmes, they are seemingly involved or involved to a limited extent.

${ }^{1}$ D. Folga-Januszewska, Muzeum: fenomeny i problemy, Kraków 2015, p. 136.

${ }^{2}$ G. Black, Transforming Museums in the Twenty-first Century, London and New York 2012, p. 7.

3 Ibidem, p. 3.

${ }^{4}$ Ibidem, p. 10.

5 N. Simon, The Participatory Museum, Santa Cruz 2010. 
Cross-sectional research of museum audiences is missing in Poland and its urgency has been voiced by museum specialists. ${ }^{6}$ Museum audiences are a part of the discussion on the role of education in museums which was initiated by the Forum of Museum Educators. In 2009-2010 the Forum conducted an in-depth research project in this field and published the report "Edukacja muzealna w Polsce. Sytuacja, kontekst, perspektywy rozwoju" [Museum education in Poland. Situation, context and perspectives for development], however, only the perspective of museums was researched, an analysis of the audiences was not included. Discussion on museum audiences and education was continued in further publications by Marcin Szeląg, ${ }^{7}$ it was also raised at the $1^{\text {st }}$ Congress of Polish Museologists (2015 in Łódź). Moreover, concrete participatory projects were discussed in several articles. ${ }^{8}$ The present study signals the subject matter with regard to participatory programmes and previews my research project on young audiences in museums as an essential area of research.

Programmes of various scope and character conducted by Polish art museums demonstrate two major strategies for engagement: 1) Visitors as creators of the concept, 2) Visitors as creative users of the content. These strategies will be discussed using four case studies. They will be preceded by discussion of the context of museum boom in Poland at the turn of the $21^{\text {st }}$ century and an overview of perceptions of museum participation in Polish museums.

\section{Context of the museum boom in Poland}

Since the 1990s, and especially since the 2000s, Polish museums have been making up for the time lost during the period of communism when investments in museum infrastructure were rather scarce. New institutions have flourished - among them museums devoted to contemporary art and of history are most numerous. ${ }^{9}$ Four new

${ }^{6}$ M. Szeląg, Rekomendacje. Główne kierunki rozwoju edukacji muzealnej w Polsce w opracowaniu uczestników seminariów z cyklu „Raport o stanie edukacji muzealnej w Polsce. Suplement” [in:] M. Szeląg (Ed.), Raport o stanie edukacji muzealnej. Suplement. Część 1, Kraków 2014, p. 29; M. Niezabitowski, Zwiedzajacy - widz czy aktor wspóttworzacy doświadczenie muzealne? Uwagi na temat zmian determinujących recepcję muzeum [in:] M. Wysocki (Ed.), I Kongres Muzealników Polskich, Warszawa 2015, p. 124.

7 M. Szeląg (Ed.), Raport... Część 1; idem, Raport o stanie edukacji muzealnej. Suplement. Część 2, Kraków 2014.

${ }^{8}$ E.g. L. Karczewski, Sztuka czy zupa. Społeczna odpowiedzialność edukacji muzealnej, "Muzealnictwo" 2015, No. 56, pp. 152-162; A. Knapek, W muzeum wszystko wolno, czyli pięć zmystów partycypacji, "Muzealnictwo" 2016, No. 57, pp. 139-148.

9 This issue was discussed in: K. Jagodzińska, Czas muzeów w Europie Środkowej. Muzea i centra sztuki wspótczesnej (1989-2014), Kraków 2014. It was also signaled in: K. Jagodzińska, Museum boom continues: on the phenomenon of museums of contemporary art from a Central European perspective, "Zarządzanie w kulturze" 2016, Vol. 17, No. 1, pp. 9-29. 
art museums have been established, ${ }^{10}$ and several museums gained new buildings or went through major redevelopments. ${ }^{11}$ National museums encompassing cross-section of art have been remodelled, some await major investments, and new branches of national museums were opened. ${ }^{12}$ At the same time, existing national, regional and local museums have been modernised and extended. Not only museums are being created, also art centres constitute an important part of the panorama of contemporary culture in Poland, with five major new institutions..$^{13}$ The year of 2004 when Poland joined the European Union brought an impetus of architectural commissions and of newly created public art collections. ${ }^{14}$ Once the most burning issues of transition period were dealt with, there came a period of prosperity for investments in culture, which were largely made possible thank to the EU funding.

New infrastructure that meets contemporary standards of cultural institutions, offers not only much needed new exhibition and storage space, but also introduces education rooms and facilities providing comfort to visitors - enlarged reception areas with comfy seating, open reading and computer rooms to explore museum's collections, cafes, and specialised bookshops.

\section{Context of participation in museums}

Historically museums were focused on safeguarding their collections and access for visitors was limited. Creation of public museums in $18^{\text {th }}$-century France and Great Britain did not abolish limitations - some museums were open on specific days for specific groups (e.g. Louvre), it was necessary to apply for a ticket to enter (e.g. British Museum). The notion of the "temple of art" (coined to represent architecture of museums following the patterns of Greek and Roman temples) attributed to art museums summarises the character of an institution (noble, prestigious, isolated from the outside world and ordinary matters) and position of a visitor (an intimidated guest).

${ }_{10}$ The Manggha Museum of Japanese Art and Technology (2004), the Museum of Modern Art in Warsaw (2008) - in a temporary building, the Museum of Contemporary Art MOCAK in Kraków (2010), the Contemporary Museum Wrocław (2011) - in a temporary building.

${ }^{11}$ Among them the Museum of Art in Łódź (2008), the Modern Art Gallery - Red Granary branch of the Leon Wyczółkowski District Museum in Bydgoszcz (2009), the Centre for the Documentation of the Art of Tadeusz Kantor CRICOTEKA (2014), the Silesian Museum in Katowice (2015).

12 Branches of the National Museum in Krakow: the Bishop Erazm Ciołek Palace (2007), the Feliks Jasieński Szołayski House (2012), the Hutten-Czapski Museum (2013), EUROPEUM - European Culture Center (2013), the Józef Czapski Pavilion (2016). New branch of the National Museum in Wrocław: the Four Domes Pavilion (2016).

13 The Łaźnia Centre for Contemporary Art in Gdańsk (1997), the Wyspa Institute of Art in Gdańsk (2004), the "Signs of the Time" Centre for Contemporary Art in Torun (2008), the Centre for Contemporary Art TRAFO in Szczecin (2013), Mazovian Centre of Contemporary Art "Elektrownia" in Radom (2014).

1415 regional contemporary art collections in the regions were created within the "Signs of the Time" programme introduced by the Minister of Culture in 2004. 
This label is up-to-date in many cases even today as it is associated with philosophy of a given museum. In the $20^{\text {th }}$ century also new categories of museums have entered the museum practice - museum-as-entertainment and museum-as forum. ${ }^{15}$ They can be discussed on many levels, referring to social and political roles, programming, as well as the position of a visitor within an institution. While museum-as-temple represents a conservative model and museum-as-entertainment has populist character, ${ }^{16}$ Katarzyna Murawska-Muthesius and Piotr Piotrowski argue that "the museum-as-forum is a democratic project which aims to grant space and voice to minorities and social critics." ${ }^{17}$

When he held a position of director of the National Museum in Warsaw (MNW) in 2009-2010, Piotrowski attempted to bring the formula of a critical museum which is directly related to the category of the museum-as-forum - to the MNW. ${ }^{18}$ According to his definition:

[...] a critical museum as a museum-forum [is] engaged in public debate, undertaking important and often also controversial problems of a given community, regarding both past and the present. A critical museum is an institution working for democracy based on argument, but also an autocratic institution reviewing its own tradition, taking issue with its own authority and the historical and artistic canon it has shaped. ${ }^{19}$

He failed, but turmoil around new concepts and programmes of the museum sparked a heated debate in Poland on the role of the contemporary museum. Meanwhile other museums in Warsaw successfully adopted the critical model, especially the Museum of Modern Art and the Museum of the History of Polish Jews.

The formula of the museum-as-forum enhances critical thinking and participation. The word "participation" was adopted for the museum practice quite recently. The term is most commonly used in social and political sciences where it addresses processes of democratisation and aims to minimise distance between the state and citizen, increase public trust towards formal institutions, develop interest of citizens in public matters and build conviction that their actions may lead to desired change. ${ }^{20} \mathrm{In}$ museums participation is most often associated with education, learning, and public programmes. Not coincidentally participatory programmes are usually run by education departments - this is the case of all case studies presented in this article.

${ }^{15}$ K. Murawska-Muthesius, P. Piotrowski, Introduction: From Museum Critique to the Critical Museum [in:] K. Murawska-Muthesius, P. Piotrowski (Eds.), From Museum Critique to the Critical Museum, Farnham-Burlington 2015, p. 6.

${ }^{16}$ Ibidem, p. 7.

${ }^{17}$ Ibidem.

${ }^{18}$ More on this concept in: P. Piotrowski, Muzeum krytyczne, Poznan 2011; idem, Making the National Museum Critical [in:] K. Murawska-Muthesius, P. Piotrowski (Eds.), op.cit., FarnhamBurlington 2015.

${ }_{19}$ P. Piotrowski, op.cit., p. 9.

${ }^{20}$ P. Poławski, Technologie partycypacji [in:] A. Przybylska, A. Giza (Eds.), Partycypacja obywatelska. Od teorii do praktyki spotecznej, Warszawa 2014, p. 30. 
Short questionnaire surveys were administered in March-April 2016 among directors of 46 museums (covering cross-section of museums in Poland concerning the character of collections, location, size and formula of management are concerned $)^{21} \mathrm{dem}-$ onstrated that they have a good understanding of what a participatory museum is. The directors usually linked participatory museum to: 1) active involvement of visitors, 2) engagement, and 3) co-creation of the programme. Some respondents indicated that such a museum is a partner for local community and co-participant of the public sphere. An argument given by one of the respondents provides a very accurate definition:

A museum should be a place of true meeting of various points of view and sensivity, as well as a place that invites to take up an initiative. If a museum is to play a lively role in contemporary life, it cannot remain an institution distributing knowledge ex cathedra, but it has to participate in the public sphere and stimulate development of an individual visitor. These functions can only be realised through partnership. ${ }^{22}$

Nina Simon, author of the book The Participatory Museum and director of the Museum of Art and History in Santa Cruz, USA (which she managed to save from closing down thank to participatory programmes for local communities), is an internationally known advocate of the participatory museum. She argues that a participatory cultural institution

[...] is a place where visitors can create, share, and connect with each other around content. Create means that visitors contribute their own ideas, objects, and creative expression to the institution and to each other. Share means that people discuss, take home, remix, and redistribute both what they see and what they make during their visit. Connect means that visitors socialize with other people - staff and visitors - who share their particular interests. Around content means that visitors' conversations and creations focus on the evidence, objects, and ideas most important to the institution in question. ${ }^{23}$

Simon defined four models of public participation in cultural institutions: contribution, collaboration, co-creation and hosted. Their common denominator is engagement of visitors, however, dimension and scale of one's involvement to the project is different. Contributory projects are least laborious for institutions and involve incorporating simple tools. Simon argues that in this model

visitors are solicited to provide limited and specified objects, actions, or ideas to an institutionally controlled process. Comment boards and story-sharing kiosks are both common platforms for contributory activities. ${ }^{24}$

${ }^{21}$ The sample was not representative. Survey was sent out and filled by only a handful of museum directors, but it illustrates a tendency. More in: K. Jagodzińska, Granice partycypacji w muzeum?, "Muzealnictwo" 2016, No. 57, pp. 112-121.

${ }^{22}$ Ibidem, p. 114.

${ }^{23}$ N. Simon, The Participatory Museum, on-line version: Preface, http://www.participatorymuseum.org/preface/ [access: 29.08.2016].

${ }^{24}$ N. Simon, The Participatory Museum, on-line version: Chapter 5: Defining Participation at Your Institution, http://www.participatorymuseum.org/chapter5/ [access: 29.08.2016]. 
Collaborative projects regard collaboration as taking place within strictly defined frames set by museums. Simon observed that in this model "visitors are invited to serve as active partners in the creation of institutional projects that are originated and ultimately controlled by the institution." ${ }^{25}$

Co-creative projects are the most demanding and time consuming for museums. Co-production of a project with visitors requires more time and workload for museum staff than the same project conducted without outside collaborators. In this model:

[...] community members work together with institutional staff members from the beginning to define the project's goals and to generate the program or exhibit based on community interests. [...] The staff partners with visitors to co-produce exhibits and programs based on community members' interests and the institution's collections. ${ }^{26}$

Unlike co-creative projects, hosted projects are least demanding - the role of institution is limited to offer space and basic services. In this case:

[...] the institution turns over a portion of its facilities and/or resources to present programs developed and implemented by public groups or casual visitors. [...] Institutions share space and/or tools with community groups with a wide range of interests [...] Hosted projects allow participants to use institutions to satisfy their own needs with minimal institutional involvement. ${ }^{27}$

This classification is very broad - from limited interaction of the visitor, through more time-consuming involvement, towards full engagement. All those strategies open up museums to various audiences. They are complementary to each other, can be applied simultaneously for various projects of one museum, and are also open for modifications and intermingling.

Only recently have these types of projects been more frequently tested by Polish museums. But it does not mean that before such collaborative models of working with audiences were completely absent from museum practice. The Laboratory of Creative Education founded in 1989 within the institutional frame of the Centre for Contemporary Art Ujazdowski Castle in Warsaw has realised numerous participatory projects ever since, on-site and outside the Centre. ${ }^{28}$

Even though contributory projects are the easiest to realise, they are still not very common. I have selected four participatory projects to discuss in the present article. They can be classified as collaborative and co-creative. The project "Anything Goes" realised by the National Museum in Warsaw is discussed in the category 'Visitors as

${ }^{25}$ Ibidem.

26 Ibidem.

${ }^{27}$ Ibidem.

${ }^{28}$ Selected books accompanying the projects: J. Byszewski, M. Parczewska, Projektowanie sytuacji twórczych / Designing creative situations, Warszawa 2004; iidem (Eds.), Dom, moje centrum świata: relacja z relacji: projekt artystyczny, społeczny, edukacyjny, Supraśl 2003, Warszawa 2005; iidem, Muzeum jako rzeźba społeczna, Warszawa 2012. 
creators of the concept', while the "Selfservice Museum" realised by the Contemporary Museum Wrocław, the "ms3 Re:action" conducted by the Museum of Art in Łódź, and the "Free Museum in Wolnica Square. Kazimierz Collective" realised by the Ethnographic Museum in Kraków are discussed in the category 'Visitors as creative users of the content.'

\section{Visitors as creators of the concept}

In 2015 director of the National Museum in Warsaw, Dr Agnieszka Morawińska conceived the idea to invite children to the Museum and inspire them to create the concept of a temporary exhibition. The project entitled "Anything Goes" (Ill. 1-2) was produced by the education department. Sixty-nine children at the age between 6 and 14 attended the programme and regularly participated in weekly three-four hour long meetings held from June 2015 until February 2016 (only with holidays breaks). Divided into six groups, supervised by museum educators, children became familiar with the specificity of various aspects of museum work. The first major step was visiting the storage areas to select artworks for the exhibition. Young curators not only watched and listened to museum keepers presenting objects from various collections, but they also had a chance to hold them in their hands. This way a barrier between an exhibit and visitor disappeared and children discovered the museum in a way that is normally inaccessible. In the course of the project children also met employees of various departments - keepers, conservators, graphic designers, arrangers, and got familiar with all stages of production of an exhibition. The fruit of the project was the professionally prepared exhibition (held from February to May 2016) comprising six rooms, each conceived by a different group of curators. In total, 300 artworks from Museum's collection were on view, framed by an appealing exhibition design.

The title of the project was supposed to emphasise the openness of the museum for all audiences, for unconventional ideas, and for individual interpretations. Young curators were encouraged to use their imagination and build an exhibition that they themselves would like to visit in a museum and at the same time an exhibition they would like to invite their peers and adults to. The project can be discussed from many perspectives. For visitors it was a refreshing experiment showing how non-art historians look at museum collections. For museum staff - keepers, curators, educators it demonstrated how a group normally staying outside processes taking place behind the "staff door" of the museum, now learned about those processes and tested them in practice. And finally for young curators it was one of a kind experience related to getting to know the museum institution, and most of all a programme that enabled them to develop creativity, learn how to discuss, argue, speak up, reach compromises, work in a team and gain many other skills.

The project recalls programmes implemented in the Anglo-Saxon countries where museums collaborate on regular basis with concrete segments of audiences (e.g. young audiences), which work on conceiving museum programme and also act 


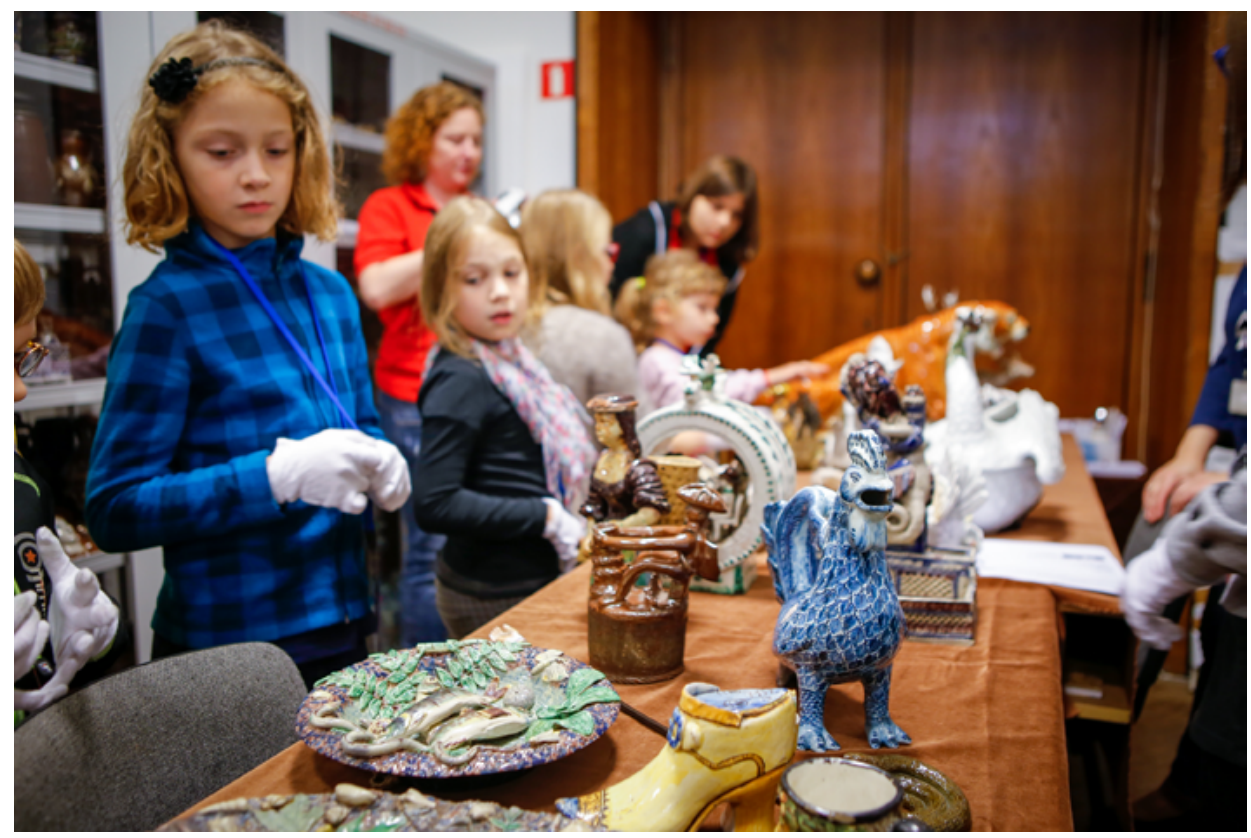

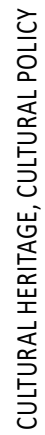

III. 1. Project "Anything Goes" - young curators in the museum storage of ceramics, 2015-2016, National Museum in Warsaw. Photo by Patryk Grochowalski, courtesy of the National Museum in Warsaw

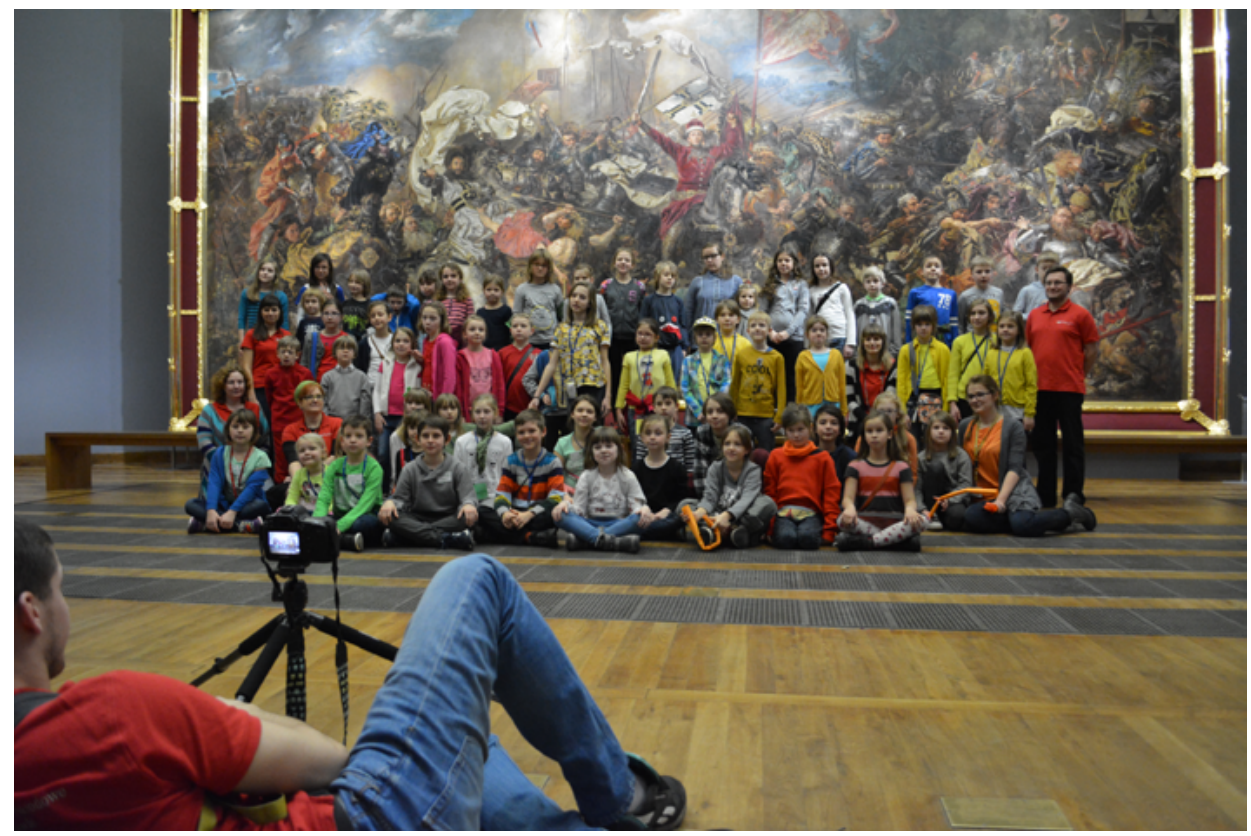

III. 2. Project "Anything Goes" - group photo of young curators, 2015-2016, National Museum in Warsaw. Photo by Katarzyna Jagodzińska 
as advisory bodies. The Young Tate, renamed as Tate Collectives, run by the Tate Gallery in the UK, is a good example of such programme. ${ }^{29}$

The project was conceived as exemplary on Polish ground and meant to serve as an inspiration for other museums. Extensive documentation of the project is easily available: videos and recordings used in the audioguides and recorded seminar for museum educators are available on-line, there was published a book presenting the making of the project; the project was evaluated by a group of researchers and the final report is also available on museum website. It gives a good insight into both positive and negative aspects of the project, and investigates changes brought for all its actors: children curators, their parents, tutors working with children, museum staff and visitors of the exhibition, as well as discusses reception of the project.

\section{Visitors as creative users of the content}

Almost since its opening in a temporary building in 2012, the Contemporary Museum Wrocław has launched an ongoing project, the "Self-service Museum" (Ill. 3). The museum occupies an anti-raid shelter built during the World War II, is circular in shape with exhibition rooms arranged around the central staircase, and the project is situated on the second floor of the five-floor massive edifice. The "Self-service $\mathrm{Mu}$ seum" is a living work of art developed by Patrycja Mastej. Until the end of 2016 eight parts of the project were realised, each one devoted to different subject, but all of them based on activity of a visitor. Magdalena Skowrońska, curator of educational programme, remarks that:

It is a place where a visitor can forget about the outside world and rules normally followed in museums. One is allowed to touch everything, to laugh, to roll on the ground, to dance ("Uzewnętrzniacz" project, 2014/2015), to relax and even to fall asleep ("W Ziemi" project, 2015/2016). Visitors can also actively co-create the space that is left over by other visitors. ${ }^{30}$

The space is composed as an artistic playground, open for modifications, rearrangements, and freedom of expression. It is targeted to general audience, the only requirement is willingness to play. But it can also be considered as a work of art to look at by those reluctant to engage.

Also the Ethnographic Museum in Kraków (MEK) stands out as the organiser of long term participatory projects. In 2013 the museum in collaboration with the Centre of Prevention and Social Education PARASOL launched the project "Wolne muzeum na Wolnicy. Kolektyw Kazimierz" [Free Museum in Wolnica Square. Kazimierz Collective - the name in Polish is based on the play of words] $]^{31}$ (Ill. 4) which was con-

${ }^{29}$ More about the Young Tate in: K. Jagodzińska, Granice partycypacji..., pp. 112-121.

${ }^{30}$ E-mail interview with Magdalena Skowrońska, curator of educational programme in the Contemporary Museum Wrocław, 31 August 2016.

${ }^{31}$ In 2013-2016 it was a part of the "Rakowicka 10" project lead by PARASOL. Since 2016 it is again run by the MEK. 


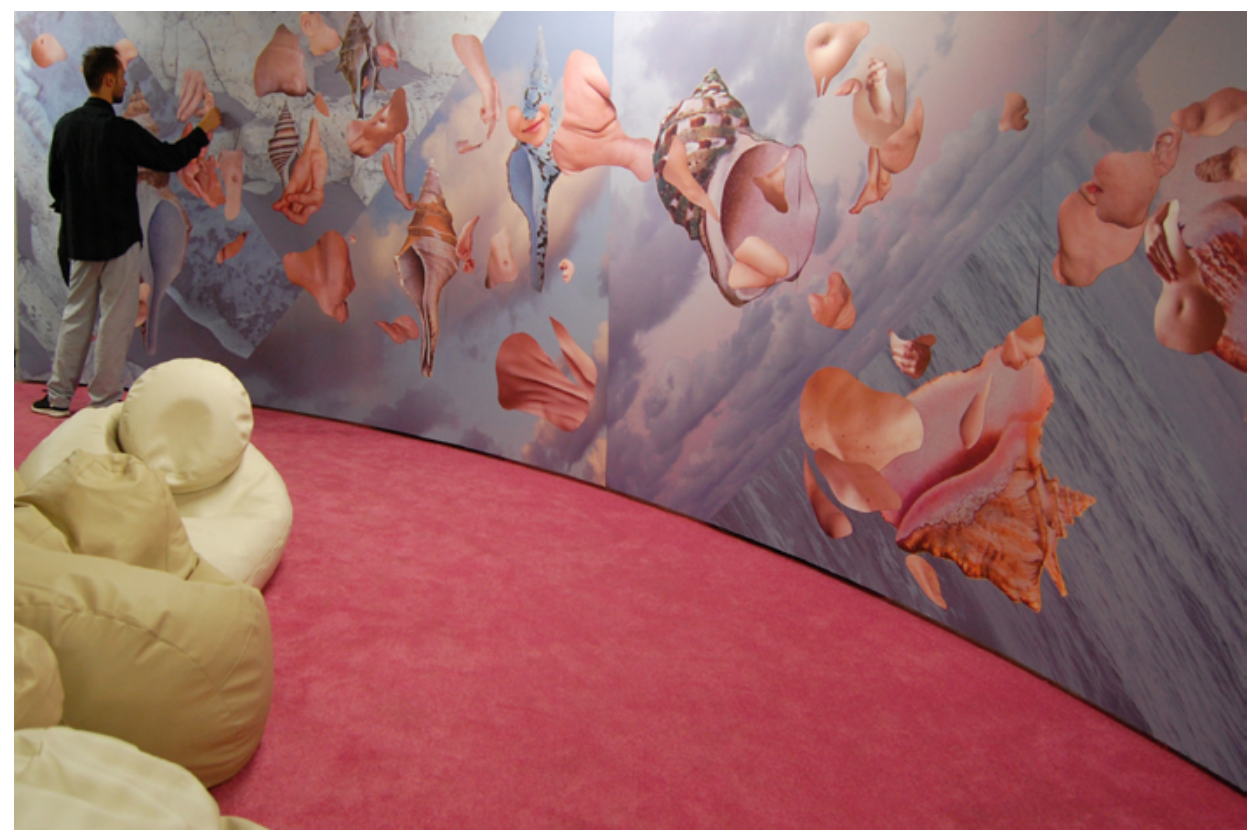

III. 3. Patrycja Mastej, "Uzewnętrzniacz" (part of the "Self-service Museum"), 2014, interactive exhibition in the Contemporary Museum Wrocław. Photo by Patrycja Mastej

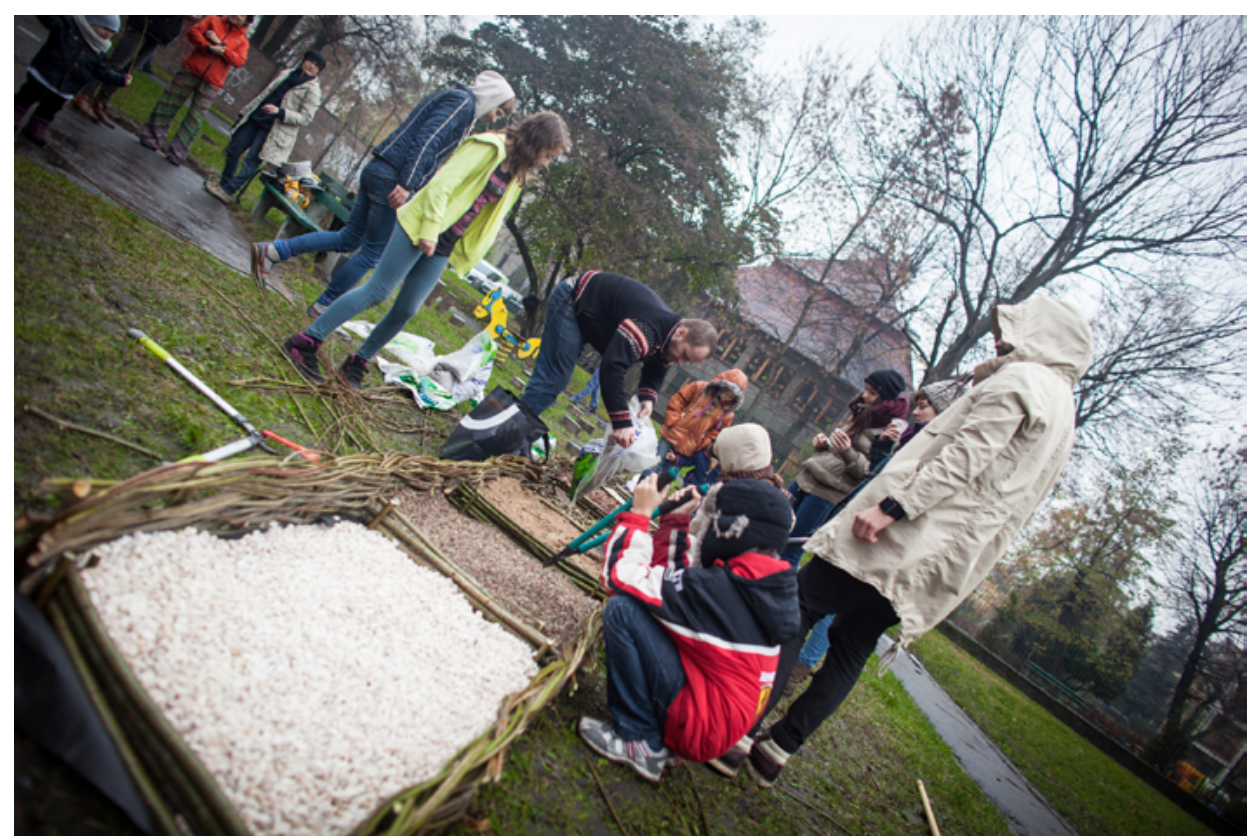

III. 4. "Natural Play Garden" initiated in 2015 (part of the project "Free Museum in Wolnica Square. Kazimierz Collective"), Ethnographic Museum in Kraków. Photo by Marcin Wąsik from the archive of the Ethnographic Museum in Kraków 
ceived as building connections with the neighbourhood of the museum located in the Jewish district, Kazimierz, and work with its history and identity. Children and youth living in the area were a target group of the project. Together with museum staff they explored the district and took up activities that were supposed to bring social change. The framework of the project allowed some autonomy for participants who became authors and organisers of particular actions. In the course of the project a rundown backyard, selected by children themselves, was regenerated. Organisers of the project explained: "We help developing a new perspective on the area, we arrange meetings with people from various backgrounds, we support individual discoveries. This experience enhances sense of self-confidence for project participants and opens them up to opportunities which are within reach." ${ }^{32}$

In 2015 the MEK initiated the creation of the "Natural Play Garden." Inhabitants of the district indicated in questionnaires and interviews that well-arranged green spaces where one could rest, meet neighbours and escape, as well as where children could play, were missing in the area. ${ }^{33}$ This is how the idea to provide such a place was developed. The design of the garden was constructed with natural materials: wood, gravel, sand, cones, wicker and vegetation, and was based on children's ideas voiced during special workshops. In 2016 a series of workshops were held with the goal to create an archive of the Kazimierz district. Current observations of participants were juxtaposed with historic documents from museum's archive and thus allowed the visitor to grasp changes taking place in the district over the years. Dr Antoni Bartosz, director of the MEK, concluded:

This project allows us to get to know a piece of real world from the nearest vicinity of the Museum. We are learning not only about particular groups of people, but also about their conditions of life, and about individual people. We get to know fantastic organisations that work here and with whom we create common language. ${ }^{34}$

On the other hand, the Museum of Art in Łódź organised several short- term projects with a participatory component. Shortly after the opening of the $\mathrm{ms}^{2}-$ new branch of the Museum of Art in Łódź with permanent exhibition of the collection of modern and contemporary art - the two-month-long project "ms3 Re:akcja" [Re:action] (Ill. 5) was launched in 2009. Its central element was the "living" exhibition realised in the main room for temporary exhibitions. It was based on the idea to embolden visitors to contemporary art and engage them in the museum processes, spanning from creation of the works of art, through collecting and exhibiting, leading to interpretation. ${ }^{35}$ Visitors took on the roles of artists (following the slogan of Joseph Beuys that "everybody is an artist") and of curators. These art and curatorial con-

32 Raport, p. 23.

${ }_{33}$ Press release: Niezwyczajny OGRÓD ZABAW przy ul. Piekarskiej, Muzeum Etnograficzne im. Seweryna Udzieli w Krakowie, 29 October 2015.

${ }^{34}$ E-mail interview with Dr Antoni Bartosz, director of the Ethnographic Museum in Kraków, 28 July 2016.

${ }^{35}$ RE:AKCJA, http://msl.org.pl/pl/program/archiwum/re-akcja.html [access: 8.08.2016]. 


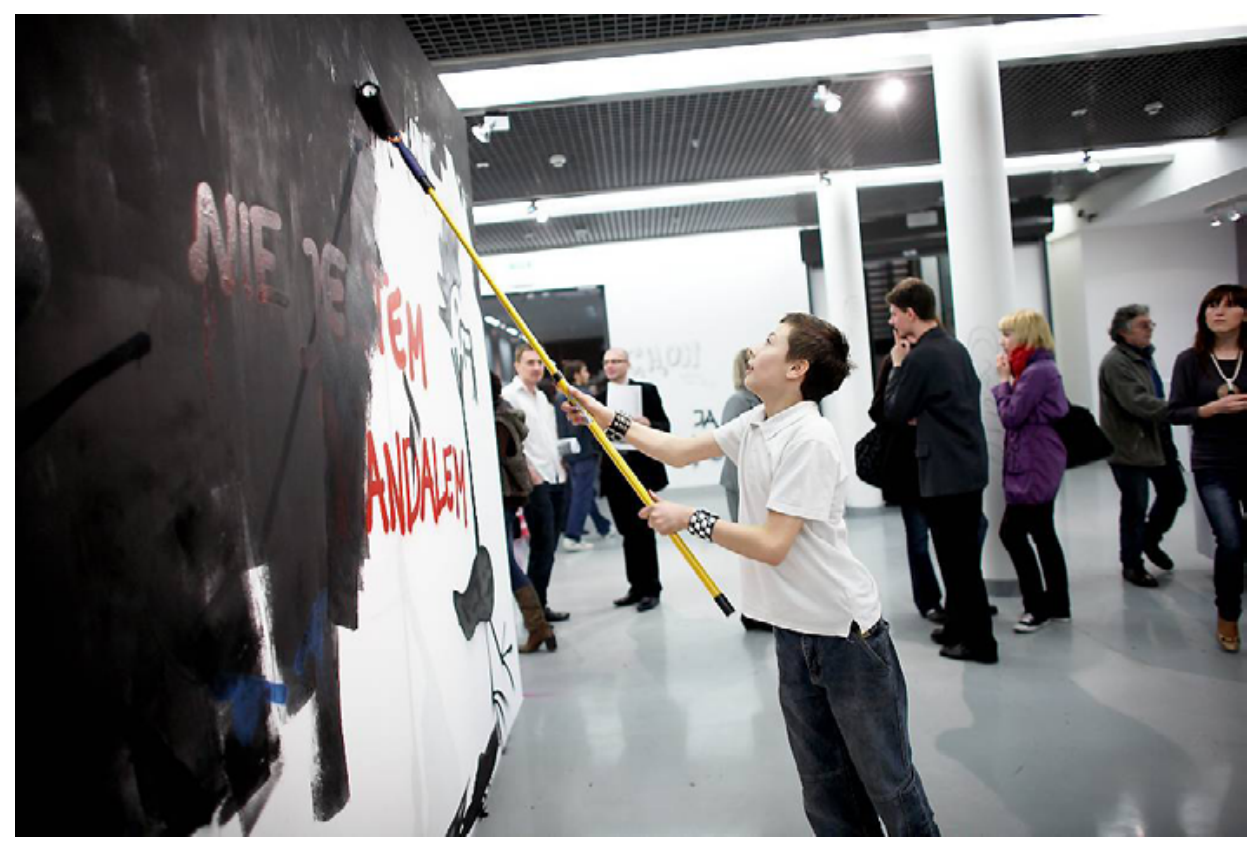

III. 5. Exhibition "ms3 Re:akcja" [Re:action], 2009, Museum of Art in Łódź. Photograph by the Museum of Art in Łódź

cepts also referred to the historic collection of modern art assembled by Władysław Strzemiński, on view on the upper floors of the museum. Visitors-participants were offered paint, crayons, brushes and painting rolls, and encouraged to follow a simple instruction: add, deduct, switch and replace. Visitors could also bring their own objects to the gallery, and in this way exhibition was growing daily.

The project was an experiment conceived to open the museum up to new audiences (special attention was given to people living in the vicinity of the Museum) and find out how relevant the museum of contemporary art can be. Museum staff only initiated creative process and provided tools of expression, while visitors were offered freedom in the gallery. ${ }^{36}$ The general rule was that the slogans, paintings, drawings, and pieces of art would not be censored because every interaction with the museum inspired reactions of other visitors. It was pointed out in a newspaper published regularly at the occasion of the project that "It is a game and no one knows the result. Only one thing is certain: the result of the two-month-long socio-artistic action will be a surprise to everybody." 37

${ }^{36}$ M. Ludwisiak, Skuteczność jest gdzie indziej. Od konfliktu do afektywnej wspólnoty [in:] T. Załuski (Ed.), Skuteczność sztuki, Muzeum Sztuki w Łodzi, 2014, p. 422.

${ }_{37}$ M. Bohdanowicz, Proszę nie niszczyć, "ms3 | Re:akcja akcja społeczno-artystyczna" 10.04.2009, No. 2/8, p. 4. 


\section{Who benefits and what is the gain?}

The four projects presented above regard very different character and degree of involvement of museum audiences. They are illustrative of the changing role of a museum visitor in Polish museums, however, they are not representative. Although the idea of participation has been employed by various types of cultural institutions in Poland, and it has generally positive connotations, but not all museums are eager to adopt it in their daily practice. What is interesting, most of museum directors who answered my questionnaire survey (mentioned earlier in this article) conceived the museum they lead as participatory, while an overview of educational programmes organised by Polish museums demonstrates that only a small number of them can be classified as such. It should be noted here that organisation of a single participatory project/programme does not qualify a museum to a label "participatory." Nevertheless, museums pay more and more attention to their audiences what is indeed visible in professional discussions in museum forums.

Expectations of people are changing, models of using culture are evolving, and thus museums respond to them accordingly. Magdalena Skowrońska rightly points out that "in composing their programmes institutions changed their attitude towards the relationship between an institution and its visitor: the institution is for the visitor, not a visitor for the institution." ${ }^{38}$ Selected case studies demonstrate that museums adopt various strategies to become meaningful and relevant (as Nina Simon put it in her recent book ${ }^{39}$ ) to visitors. These projects are not just accidental whims of educational teams or tools for building up attendance numbers, but they are all grounded in the identity of institutions and realise their (new?) philosophy. In the case of the MEK its director explains:

On the one hand, less and less depend on us, as globalisation processes are growing and pres-
sure of financial, political and ideological interests have had increasing influence on our
lives. On the other hand, more and more things depend on us [...]. Museums can greatly sup-
port this direction towards identity, which can be realised not through unilateral communique,
but through building partnerships, inviting people to participate in building the content and ac-
tivities, enabling valuable reflection and inscribing it in today's horizon. ${ }^{40}$

Programmes allowing participation are beneficial for both sides - visitors gain knowledge, skills, experience, satisfaction, enjoyment, and on the other side museums learn about people they address and about neighbourhoods where they operate. Researchers who conducted evaluation of the MNW project ${ }^{41}$ identified three groups of results that the project had in the group of young curators:

\footnotetext{
${ }^{38}$ E-mail interview with Magdalena Skowrońska...

${ }^{39}$ N. Simon, The Art of Relevance, Museum 2.0, 2016.

${ }^{40}$ E-mail interview with Dr Antoni Bartosz...

${ }^{41}$ The aims of the project were not defined by the organisers in the first place.
} 
1) in the social sphere results encompassed democratisation, sense of self-worth, sense of agency, increase of the authority in family and at school, ability to negotiate, courage, openness towards adults, skill of self-presentation;

2 ) in the educative sphere results encompassed knowledge of how an exhibition is constructed, knowledge of the character of work in the museum, respect for the work of art, sense of competences, knowledge of the promotion;

3 ) in the artistic sphere results encompassed ability to create, sense of freedom, ability to discern details of the exhibits and to see art through the prism of emotions. ${ }^{42}$

The Contemporary Museum Wrocław treats its participatory project as an introduction to contemporary art exhibitions presented in other rooms of the museum. Magdalena Skowrońska remarks that by 'using the 'Self-service Museum' visitors can react in more open and spontaneous way to contemporary art, which normally requires engagement and reflection, not only looking at." ${ }^{43}$

Also museums gain in the process of realisation of participatory projects. Participants of projects realised by the MEK are in some sense councillors to the museum. Projects following ideas of participants enable museums to learn about their interests and expectations in the most straightforward way: simply by asking and providing space to realise people's ideas. Bożena Pysiewicz, deputy head of the Education Department in the MNW and coordinator of the "Anything Goes" project argues that people who engage in museum activities (in various forms):

[...] are not one time visitors treating the Museum as one of many tourist attractions, but they are active audience that has an impact on the shape of the institution. By filling out evaluation questionnaires they suggest topics for meetings, lectures, workshops. They also often recommend visiting the Museum to their families and friends, what makes them our ambassadors. ${ }^{44}$

Those people identify with the institution. Realisation of participatory projects often engages cross-institutional cooperation and thus breaks the daily routine of museum practice encouraging staff to learn about other domains of the institution, outside their duties. In the case of the MNW project Pysiewicz admitted that "joint work on this special exhibition allowed staff regularly preparing exhibitions to understand the nature of work of museum educators, and reverse - educators learned about new areas of museum work with which they did not have contact before." ${ }^{45}$

Participatory projects are not the only ones where a visitor occupies central position in a museum, however, here engagement is of key importance - without it a project does not make sense. Engagement can be long-term and in-depth, like in Warsaw and Kraków, it can also be one-time, involving a visitor just for a moment, like in

${ }^{42}$ See: M. Szostakowska, I. Pogoda, Ewaluacja projektu "W Muzeum wszystko wolno". Raport, [2016], p. 13.

${ }_{43}$ E-mail interview with Magdalena Skowrońska...

44 E-mail interview with Bożena Pysiewicz, deputy head of the Education Department in the National Museum in Warsaw and coordinator of the "Anything Goes" project, 23 August 2016.

${ }^{45}$ Ibidem. 
Wroclaw and Łódź. Many museums remain either conservative or follow other strategies for opening up. Nina Simon asks: "does every visitor really want to participate in this manner in cultural institutions?" and realistically answers:

\begin{abstract}
No. Just as there are visitors who will never pull the lever on an interactive and those who prefer to ignore the labels, there are many visitors who will not choose to share their story, talk with a stranger, or consume visitor-generated content. There will always be visitors who enjoy static exhibitions conferring authoritative knowledge. There will always be visitors who enjoy interactive programs that allow them to test that knowledge for themselves. And there will increasingly be visitors - perhaps new ones - who enjoy the opportunity to add their own voices to ongoing discussions about the knowledge presented. ${ }^{46}$
\end{abstract}

This observation is supported by one of the exhibition guards in the $\mathrm{ms}^{2}$ who described various models of engaging in the "ms3 Re:action" project, including people who only come to look at, not to participate in creation:

[visitors-participants] Asked for help, for crayons, for paint, for a ladder, asked whom they can talk to and whether they are really allowed to paint over the walls. There were people who wanted to arrange a group visit. There were people who came to the ms 3 only to have a look. And people who in the beginning did not plan to paint anything, but when it turned out that it is possible, they decided to take this opportunity. There were also people who came well prepared, they even had their own paint and brushes, and covered fragments of walls according to designs they previously made. Sometimes walls were even especially prepared beforehand. ${ }^{47}$

There are always those who eagerly take up new opportunities and those who consider daring actions as inappropriate for a noble museum. But it is up to a museum how much participation there will be. It is usually selected programmes offered in this framework, while the other ones available simultaneously in a museum are more traditional. Just as Simon points out: "participation is an and, not an or." 48

My observation is that museums are largely reluctant to give away their power. This issue leads to the question: How much freedom are museum leaders ready to hand over to visitors and how much do they actually give away? If statistics were made among Polish museums regarding participatory aspect of museum programmes, they would surely demonstrate that not much freedom is offered to visitors. Projects presented in this article prove that museums indeed share power with visitors, however, in a limited way and within the frame they constitute. In my view it is museum leaders and staff anxiety whether visitors would be able to benefit from a visit without competent guidance and some sort of surveillance that stops museums from fully opening up to participatory strategies. Simon writes that "Supporting participation means trusting visitors' abilities as creators, remixers, and redistributors of content. It

${ }^{46}$ N. Simon, The Participatory Museum, on-line version: Chapter 1: Principles of Participation, http://www.participatorymuseum.org/chapter1/ [access: 29.08.2016].

${ }^{47}$ E. Kamińska-Podkówka, Lubię, jak coś się zmienia, "ms3 | Re:akcja akcja społecznoartystyczna" 22.05.2009, No. 8/8, p. 2.

${ }^{48}$ N. Simon, The Participatory Museum, on-line version: What's Next? Imagining the Participatory Museum, http://www.participatorymuseum.org/imagining/ [access: 29.08.2016]. 
means being open to the possibility that a project can grow and change post-launch beyond the institution's original intent." 49

In the already mentioned questionnaire survey the majority of museum directors indicated that museums have to set frames of participatory projects. There were opinions that participants need to be controlled or consulted, and that full freedom is not possible. ${ }^{50}$ This suggests that relation between a museum and visitor is not based on partnership and a visitor occupies an inferior position. Moreover, museums seem to be afraid that institutional gain will not be spectacular when compared to the workload contributed to realisation of the project.

None of the projects presented in this article is based on extensive freedom. Leszek Karczewski, head of the Education Department in the Museum of Art in Łódź, argues that a museum is not a space of freedom at all, in contrary - it is a space of exclusion. According to him decisions 'what', 'how' and 'for whom' is presented excludes objects and people in the first place. What is more:

We cannot say that we realise democratic education processes when we know everything, when we know the script, when we know what can potentially be created within the project (or at least, what surely cannot be created). ${ }^{51}$

Boundaries within which visitors operate in participatory projects are clearly visible in four case studies. Paradoxically the MNW project promised much more in its title than was actually offered as the "anything goes" philosophy was applied only on the ground of curatorship of the exhibition. And even here it had strictly defined rules. For many people the title was misleading, what was demonstrated in the evaluation report. One of young curators asked "What is allowed in the Museum?" replied: "It depends to whom, e.g. visitors can see the exhibitions, while museum staff can enter various areas, storages and other places. We are permitted similar things to the staff. However, we cannot run and shout." ${ }^{52}$

According to museum employees the title suggested space for activity and anarchy, while both children curators and visitors had to follow the rules and thus could not test themselves the "anything goes" philosophy. ${ }^{53}$ Also visitors noticed that they could not experience more freedom at the exhibition comparing to other exhibitions. ${ }^{54}$ Children worked on the concept of the exhibition, but they did not have much contribution to the final presentation of the works of art. The report indicates that in one case it even led to disappointment when one group saw their part of the exhibition mounted, as it did not fully follow their expectations. ${ }^{55}$ Still, it does not diminish the

49 N. Simon, The Participatory Museum, on-line version: Chapter $1 \ldots$

${ }^{50}$ K. Jagodzińska, Granice..., p. 115.

${ }^{51}$ Interview with Leszek Karczewski, head of the Education Department in the Museum of Art in Łódź held on 27 September 2013 by K. Jagodzińska in connection with unpublished manuscript: K. Jagodzińska, J. Strycharz (Eds.), W poszukiwaniu nowej roli muzeum.

${ }_{52}$ M. Szostakowska, I. Pogoda, op.cit., p. 16.

${ }^{53}$ Ibidem, p. 44.

${ }^{54}$ Ibidem, p. 57.

55 Ibidem, p. 14. 
significance of the project to its participants and to the museum practice. The "Selfservice Museum" offers freedom but within strict frames and with the use of tools and instruments provided by the museum. In this sense the "ms3 Re:action" went a step further as it encouraged visitors to free their imagination, and although instruments were provided, visitors could choose to bring their own objects and tools. In the case of the MEK there has been a scenario of each action, but some of them were open and allowed participants to make decisions that were followed afterwards.

\section{Looking forward}

Indeed, the activity of visitors regarding participation in museum programmes and their daily practice is limited in Poland. The number of institutions that decided to employ this model is scarce (however, not limited to museums discussed in this article), but most importantly it is growing and successful projects only encourage other institutions to follow. Bożena Pysiewicz remarks, that the "Anything Goes" project in the MNW "built the prestige of the Museum. It allowed the Museum to function as the innovative institution on an international scale, the one realising a project that did not have an equivalent in the museum practice before." ${ }^{\circ 6}$ Also an active role played by visitors in these projects is limited - they have often seeming impact on the course of the projects, nevertheless they offer interaction which fosters learning and - most of all - attachment to the institution. It should be noted that participatory projects are not dominating in museums across the globe, Poland is not an exception.

Discussion about engaging or participatory museums and the museum-as-forum is linked to another hot issue of museological debates - a museum resembling a community house. There is a fear that the merit of a museum would be diminished and that entertainment would replace education and learning. Simon brought a comparison that future museums following participatory practice "may look more like a coffee shop or a community arts center." ${ }^{57}$ This vision is something museum leaders and staff are afraid of. But it is already happening. Certainly providing that a coffee shop is not just a place where one drops in to quickly drink a coffee and go, but a 'third place' as defined by Ray Oldenburg ${ }^{58}$ where social meetings are held, where people spend their leisure time and during interactions - widen horizons and develop their intellectual capital. Division between coffee shops, community centres, museums and other types of formal and informal institutions is not sharp anymore, especially when similar strategies and tools are used. All of them can provide simultaneously entertainment and knowledge granting the visitor the central position, however the nature and the boundaries of participation are always defined by organisers of the project.

${ }^{56}$ E-mail interview with Bożena Pysiewicz...

${ }^{57}$ N. Simon, The Participatory Museum, on-line version: What's Next?...

${ }^{58}$ R. Oldenburg, The Great Good Place: Cafes, Coffee Shops, Community Centers, Beauty Parlors, General Stores, Bars, Hangouts, and How They Get You Through the Day, New York 1989. 


\section{Bibliography}

Black G., Transforming Museums in the Twenty-first Century, Routledge, London and New York 2012. Bohdanowicz M., Proszę nie niszczyć, "ms3 | Re:akcja akcja społeczno-artystyczna” 10.04.2009, No. $2 / 8$.

Byszewski J., Parczewska M. (Eds.), Dom, moje centrum świata: relacja z relacji: projekt artystyczny, spoleczny, edukacyjny, Supraśl 2003, Warszawa 2005.

Byszewski J., Parczewska M., Muzeum jako rzeźba społeczna, Warszawa 2012.

Byszewski J., Parczewska M., Projektowanie sytuacji twórczych / Designing creative situations, Warszawa 2004.

Folga-Januszewska D., Muzeum: fenomeny i problemy, Kraków 2015.

Jagodzińska K., Czas muzeów w Europie Środkowej. Muzea i centra sztuki wspótczesnej (19892014), Kraków 2014.

Jagodzińska K., Granice partycypacji w muzeum?, "Muzealnictwo” 2016, No. 57, pp. 112-121.

Jagodzińska K., Museum boom continues: on the phenomenon of museums of contemporary art from a Central European perspective, "Zarządzanie w kulturze" 2016, Vol. 17, No. 1, pp. 9-29.

Kamińska-Podkówka E., Lubię, jak coś się zmienia, "ms3 | Re:akcja akcja społeczno-artystyczna" 22.05.2009, No. 8/8.

Karczewski L., Sztuka czy zupa. Społeczna odpowiedzialność edukacji muzealnej, "Muzealnictwo" 2015, No. 56, pp. 152-168.

Knapek A., W muzeum wszystko wolno, czyli pięć zmysłów partycypacji, "Muzealnictwo" 2016, No. 57, pp. 139-148.

Ludwisiak M., Skuteczność jest gdzie indziej. Od konfliktu do afektywnej wspólnoty [in:] T. Załuski (Ed.), Skuteczność sztuki, Muzeum Sztuki w Łodzi, 2014, pp. 412-425.

Murawska-Muthesius K., Piotrowski P. (Eds.), From Museum Critique to the Critical Museum, Farnham-Burlington 2015.

Niezabitowski M., Zwiedzający - widz czy aktor wspóttworzacy doświadczenie muzealne? Uwagi na temat zmian determinujacych recepcję muzeum [in:] M. Wysocki M. (Ed.), I Kongres Muzealników Polskich, Warszawa 2015, pp. 121-128.

Oldenburg R., The Great Good Place: Cafes, Coffee Shops, Community Centers, Beauty Parlors, General Stores, Bars, Hangouts, and How They Get You Through the Day, New York 1989.

Piotrowski P., Muzeum krytyczne, Poznań 2011.

Poławski P., Technologie partycypacji [in:] A. Przybylska, A. Giza (Eds.), Partycypacja obywatelska. Od teorii do praktyki społecznej, Warszawa 2014.

RE:AKCJA, http://msl.org.pl/pl/program/archiwum/re-akcja.html [access: 8.08.2016].

Simon N., The Art of Relevance, Museum 2.0, 2016.

Simon N., The Participatory Museum, Santa Cruz 2010; on-line version: http://www.participatorymuseum.org/read/ [access: 29.08.2016].

Szeląg M. (Ed.), Raport o stanie edukacji muzealnej. Suplement. Część 1, Kraków 2014.

Szeląg M. (Ed.), Raport o stanie edukacji muzealnej. Suplement. Część 2, Kraków 2014.

Szostakowska M., Pogoda I., Ewaluacja projektu "W Muzeum wszystko wolno". Raport, [2016].

\section{Interviews:}

E-mail interview with Dr Antoni Bartosz, director of the Ethnographic Museum in Kraków, 28 July 2016.

E-mail interview with Bożena Pysiewicz, deputy head of the Education Department in the National Museum in Warsaw and coordinator of the "Anything Goes" project, 23 August 2016.

E-mail interview with Magdalena Skowrońska, curator of educational programme in the Contemporary Museum Wrocław, 31 August 2016.

Interview with Leszek Karczewski, head of the Education Department in the Museum of Art in Łódź held on 27 September 2013 by K. Jagodzińska in connection with unpublished manuscript: K. Jagodzińska, J. Strycharz (Eds.), W poszukiwaniu nowej roli muzeum. 